\title{
Hearing treshold before and after middle ear surgery in chronic suppurative otitis media (CSOM)
}

\author{
Bambang Udji Djoko Rianto*, Suwardi, Edhie Samodra \\ Departement of Otorhinolaryngology Head and Neck Surgery, \\ Faculty of Medicine, Public Health and Nursing, Universitas Gadjah Mada/Dr. Sardjito \\ General Hospital, Yogyakarta
}

DOI: http://dx.doi.org/10.19106/JMedSci005002201811

\begin{abstract}
Hearing loss is a common symptom in chronic suppurative otitis media (CSOM), often cause social communication disturbance. Canal wall up tympanoplasty and canal wall down tympanoplasty are surgery procedures for managing this disease that no response to convensional treatment. These surgery procedures should consider to hearing function impact. The aim of this study was to evaluate the difference hearing threshold between before and after middle ear surgery on CSOM patients. It was an historical cohort study conducted from January 2015 to December 2016 involving CSOM patients who underwent canal wall up tympanoplasty surgery and canal wall down tympanoplasty in The Otology Division, Departement of Ear, Nose, Throat, Head and Neck Health, Dr. Sardjito General Hospital, Yogyakarta. The inclusion criteria included basic data, diagnostics, surgery reports, and audiometry results before and 3 months postoperatively, while the exclusion criteria were not complete medical record data. Total of 64 patients with CSOM were involved in this study consisting of 32 patients who underwent canal wall up tympanoplasty and 32 patients who underwent canal wall down tympanoplasty. Significantly different in the increasing of hearing threshold between before and after canal wall up tympanoplasty surgery compared to the canal wall down tympanoplasty was observed $(p=0.021)$. In addition, surgical technique was the main factor affecting postoperative hearing threshold in CSOM patients $(p<0.05)$. In conclusion, the increasing of hearing threshold in CSOM patients underwent canal wall up tympanoplasty surgery is better than those underwent canal wall down tympanoplasty.
\end{abstract}

\section{ABSTRAK}

Penurunan pendengaran merupakan gejala umum pada penderita otitis media supuratif kronis (OMSK) yang sering menyebabkan gangguan komunikasi sosial. Timpanoplasti dengan metode canal wall up dan canal wall down merupakan tindakan bedah untuk pengelolaan penyakit ini apabila pengobatan konvensional tidak memberikan respon. Tindakan bedah ini harus mempertimbangkan efek sampingnya pada fungsi pendengaran. Tujuan penelitian ini adalah untuk mengkaji perbedaan antara ambang pendengaran sebelum dan sesudah tindakan bedah telinga tengah pada pasien OMSK. Penelitian kohort

\footnotetext{
* corresponding author: djoriant@ugm.ac.id
} 
historik ini dilakukan dari Januari 2015 sampai Desember 2016 melibatkan pasien OMSK yang menjalani timpanoplasti dengan metode canal wall up dan canal wall down di Divisi Otologi, Departemen IImu Kesehatan Telinga Hidung Tenggorok-Kepala dan Leher (THTKL), RSUP Dr. Sardjito, Yogyakarta. Kriteria inklusi adalah pasien mempunyai kelengkapan data dasar, hasil diagnosis, laporan operasi dan hasil audiometri sebelum dan 3 bulan pasca operasi, sedangkan kriteria eksklusi adalah data rekam medis pasien tidak lengkap. Total sebanyak 64 pasine dengan OMSK yang terdiri dari 32 pasien menjalani timpanoplasti metode canal wall up dan 32 pasien metode canal wall down. Terdapat perbedaan nyata perbaikan ambang pendengaran sebelum dan setelah timpanoplasti dengan metode canal wall up dibandingkan dengan metode canal wall down $(p=0,021)$. Selanjutnya terbukti, teknik bedah merupakan factor utama yang berpengruh terhadap ambang pendengaran pasca operasi pada pasien OMSK $(p<0.05)$. Dapat disimpulkan, peningkatan ambang pendengaran pasien OMSK yang menjalani timpanoplasti metode canal wall up lebih baik dibandingkan dengan metode canal wall down.

Keywords : chronic suppurative otitis media - hearing threshold - middle ear surgery tympanoplasty - audiometry

\section{INTRODUCTION}

Chronic suppurative otitis media (CSOM) is one of the chronic inflammatory diseases of the middle ear which is characterized by perforation of tympanic membrane and persistent or absent secretions that occur over 3 months. This disease still as problem in Ear, Nose and Throat field. ${ }^{1}$ The CSOM can be divided into two types i.e. benign type and danger type (maligna). ${ }^{2}$ According to other literature the CSOM can be divided into two types i.e. CSOM with kolesteatoma and CSOM without kolesteatoma. The management of CSOM is different depending on the type. ${ }^{3,4}$

The CSOM is a common worldwide disease especially in developing countries with low socioeconomic status with the prevalence varies from 0.5 to $30 \% .{ }^{5}$ Prevalence of CSOM surveys worldwide showed the global burden of illness from CSOM involved 65-330 million people with otorrhoea, $60 \%$ of whom (39-200 million) suffered from significant hearing loss. ${ }^{2}$ In Indonesia, the CSOM prevalence ranges from 3.9 up to $5.6 \%$. Data from Hearing and Illumination Health Survey conducted in seven provinces from 1994 to 1996 showed that the most common cause of middle ear morbidity was benign CSOM (3\%). ${ }^{6}$ According to the patient's medical records in Departement of Otorhinolaryngology, Head and Neck Surgery, Dr. Sardjito General Hospital Yogyakarta in 1998-1999, 40 patients with CSOM was recorded and 25 (62.5\%) of them underwent mastoidectomy surgery. ${ }^{7}$

Chronic suppurative otitis media causes damage to some or all of the tympanic membrane and affects hearing loss with a maximum reduction of $40 \mathrm{~dB}$. Tympanic membrane perforation with damage auditory ossicles may affect the hearing loss of conduction-type hearing loss by 60 to $70 \mathrm{~dB} .^{5,8}$ The type of deafness caused by CSOM in the form of conductive deafness and deafness of the mixture with the degree of deafness depends on the involvement of the hearing bones. ${ }^{9}$ Chronic suppurative otitis media can be managed with medical treatment and surgery. Tympanoplasty is a technique of middle ear surgery with the goal of eradication of pathological tissue and infection in the middle ear and reconstruct hearing mechanisms with or without graph and reconstruction of the 
hearing bones, this surgical technique can be combined with canal wall upmastoidectomy or canal wall down with the aim of eradication of disease in the mastoid region and middle ear. ${ }^{1}$

Examination of pure tone audiometry is a still relevant assessment of hearing status. Audiometry can be used to assess the presence or absence of post-surgical hearing repair in the middle ear by measuring both air delivery and bone conduction at frequencies 500, $1000,2000,4000,8000 \mathrm{~Hz}$, for the calculation of mean hearing threshold values can be measured at frequencies 500, 1000, $2000 \mathrm{~Hz}$ because these frequencies represent daily conversations. ${ }^{1,8}$ The aim of this study was to evaluate the difference hearing threshold before and after middle ear surgery between canal wall up tympanoplasty and canal wall down tympanoplasty procedures in patients CSOM.

\section{MATERIALS AND METHODS}

\section{Subjects}

This was an observational retrospective cohort study to evaluate the difference hearing threshold of CSOM patients between before and after middle ear surgery using canal wall up tympanoplasty and canal wall down tympanoplasty technique. The study was conducted over a period of January 2015 until December 2016 in the Otology Division, Departement of Otorhinolaryngology, Dr. Sardjito General Hospital Yogyakarta on CSOM patients who meet the inclusion and exclusion criteria. The inclusion criterion included basic data, diagnostics, surgery reports, and audiometry results before and 3 months postoperatively, while the exclusion criteria were not complete medical record data.

\section{Protocol of study}

All patients who presented signs and symptoms suggesting CSOM based on medical record data and underwent middle ear surgery both with canal wall up and canal wall down tympanoplasty methods by the same surgeon were identified. Thereafter, the patients were the grouped into two groups i.e. group of patients who underwent canal wall up tympanoplasty and group of patients who underwent canal wall down tympanoplasty. The audiometry was conducted following standard protocol before and 3 months after surgery. For calculation of average hearing loss four frequencies were selected i.e. 500, 1000,2000 and $4000 \mathrm{~Hz}$ and assessed by airbone conduction range (ABG). Protocol of this study has been approved by the Health Research Etics Committee of the Faculty of Medicine, Public Health and Nursing, Universitas Gadjah Mada, Yogyakarta (Ref: KE/FK/0196/EC/2017).

\section{Statistical analysis}

The differences of $\mathrm{ABG}$ at the frequency of 500, 1000, 2000 and $4000 \mathrm{~Hz}$ in each midle ear surgery method were analyzed using independent t-test. Furthermore, the difference of ABG between before and after surgery was analyzed using paired t-test. A p value $<0.05$ was considered to be significantly different.

\section{RESULTS}

Sixty four CSOM patients consisting 32 patients undergoing a canal up wall tympanoplasty and 32 patients undergoing a canal wall down tympanoplasty procedures were included in this study. The mean age of patients undergoing the canal wall up tympanoplasty was $36.78 \pm 12.21$ years with the youngest aged 18 years and the oldest aged 
60 years, whereas the mean age of patients undergoing canal wall down tympanoplasty was $32.88 \pm 14.91$ years with the youngest aged 8 years and the oldest aged 56 years (TABLE 1). No significantly different was observed in the mean age of the both groups $(p=0.246)$. Distribution of sex in the group of canal wall up tympanoplasty were $16(51.61 \%)$ male patients and 16 (48.48\%) female patients, whereas in the group of canal wall down tympanoplasty were 15 (48.39\%) male patients and $17(51.52 \%)$ female patients. No significantly different was also observed in the sex distribution of the both groups $(p=0.210)$.

TABLE 1. The basic characteristics of patients

\begin{tabular}{lccc}
\hline \multicolumn{1}{c}{ Variable } & $\begin{array}{c}\text { Canal wall up } \\
\text { tympanoplasty }\end{array}$ & $\begin{array}{c}\text { Canal wall down } \\
\text { tympanoplasty }\end{array}$ & p \\
\hline Age (mean \pm SD years) & $36.78 \pm 12.21$ & $32.88 \pm 14.91$ & $0.246^{\mathrm{a}}$ \\
Sex [n (\%)] & $16(51.61)$ & $15(48.39)$ & $0.210^{\mathrm{b}}$ \\
Male & $16(48.48)$ & $17(51.52)$ & \\
Female & & & \\
AC (mean \pm SD dB) & $46.25 \pm 13.01$ & $64.22 \pm 13.14$ & $0.001^{\mathrm{a}}$ \\
AC 500 Hz & $46.88 \pm 1.55$ & $66.72 \pm 14.73$ & $0.001^{\mathrm{a}}$ \\
AC 1000 Hz & $46.88 \pm 11.13$ & $66.41 \pm 13.33$ & $0.001^{\mathrm{a}}$ \\
AC 2000 Hz & $42.81 \pm 14.59$ & $63.13 \pm 14.91$ & $0.001^{\mathrm{a}}$ \\
AC 4000 Hz & & & \\
BC (mean \pm SD dB) & $13.75 \pm 10.63$ & $25.16 \pm 12.92$ & $0.001^{\mathrm{a}}$ \\
BC 500 Hz & $12.19 \pm 7.61$ & $27.19 \pm 11.77$ & $0.001^{\mathrm{a}}$ \\
BC 1000 Hz & $18.44 \pm 8.47$ & $30.00 \pm 14.59$ & $0.001^{\mathrm{a}}$ \\
BC 2000 Hz & $15.47 \pm 11.59$ & $30.31 \pm 14.69$ & $0.001^{\mathrm{a}}$ \\
BC 4000 Hz & & & \\
ABG (mean \pm SD dB) & $32.5 \pm 12.38$ & $39.06 \pm 14.67$ & $0.058^{\mathrm{a}}$ \\
ABG 500 Hz & $34.69 \pm 13.67$ & $39.22 \pm 18.87$ & $0.209^{\mathrm{a}}$ \\
ABG 1000 Hz & $28.43 \pm 10.88$ & $36.41 \pm 10.94$ & $0.005^{\mathrm{a}}$ \\
ABG 2000 Hz & $27.34 \pm 12.51$ & $32.81 \pm 11.21$ & $0.070^{\mathrm{a}}$ \\
ABG 4000 Hz & & & \\
\hline
\end{tabular}

Note : SD: standard deviation; AC: air conduction; BC: bone conduction; ABG: air bone gap; a:independent t-test; ${ }^{\mathrm{b}}$ : chi-square;

Table 2 show the difference between air conduction (AC) and bone conduction (BC) both group of surgical methods. For the difference of air surge increase based on surgery on each frequency $500 \mathrm{~Hz}, 1000$
$\mathrm{Hz}, 2000 \mathrm{~Hz}$ and $4000 \mathrm{~Hz}$ in both groups not statistically significant difference with $\mathrm{p}>0.05$ as in table 3, while table 4 showsthe air-bone gap between before and after surgery. 
TABLE 2. Differences AC (mean \pm SD dB) before and after surgery at each audiometric frequency

\begin{tabular}{llccc}
\hline Frequency & \multicolumn{1}{c}{ Method } & Befofe surgery & After surgery & p \\
\hline \multirow{2}{*}{$500 \mathrm{~Hz}$} & Canal wall up tympanoplasty & $46.25 \pm 13.01$ & $40.78 \pm 12.12$ & 0.006 \\
& Canal wall down tympanoplasty & $64.22 \pm 13.14$ & $59.06 \pm 16.19$ & 0.001 \\
\multirow{2}{*}{$1000 \mathrm{~Hz}$} & Canal wall up tympanoplasty & $46.88 \pm 13.55$ & $40.47 \pm 10.58$ & 0.001 \\
& Canal wall down tympanoplasty & $66.72 \pm 14.73$ & $63.28 \pm 17.63$ & 0.001 \\
\multirow{2}{*}{$2000 \mathrm{~Hz}$} & Canal wall up tympanoplasty & $46.88 \pm 11.13$ & $39.84 \pm 8.37$ & 0.003 \\
& Canal wall down tympanoplasty & $66.41 \pm 13.33$ & $62.03 \pm 16.16$ & 0.001 \\
\multirow{2}{*}{$4000 \mathrm{~Hz}$} & Canal wall up tympanoplasty & $42.81 \pm 14.59$ & $41.41 \pm 13.27$ & 0.515 \\
& Canal wall down tympanoplasty & $63.13 \pm 14.91$ & $60.00 \pm 17.60$ & 0.001 \\
\hline
\end{tabular}

Note : AC: air conduction

TABLE 3. Differences in the increase in AC (mean \pm SD dB) based on the type of surgical methode at each audiometric frequency

\begin{tabular}{cccc}
\hline Frequency & $\begin{array}{c}\text { Canal wall up } \\
\text { tympanoplasty } \\
500 \mathrm{~Hz}\end{array}$ & $\begin{array}{c}\text { Canal wall down } \\
\text { tympanoplasty }\end{array}$ & $\mathrm{p}$ \\
$1000 \mathrm{~Hz}$ & $5.47 \pm 10.5$ & $5.16 \pm 10.36$ & 0.905 \\
$2000 \mathrm{~Hz}$ & $7.03 \pm 12.17$ & $3.44 \pm 9.95$ & 0.235 \\
$4000 \mathrm{~Hz}$ & $1.4 \pm 12.06$ & $4.38 \pm 8.4$ & 0.314 \\
\hline
\end{tabular}

Note : AC: air conduction

TABLE 4. Differences ABG (mean \pm SD dB) before and after surgery at each audiometric frequency

\begin{tabular}{llccc}
\hline Frequency & \multicolumn{1}{c}{ Method } & Befofe surgery & After surgery & p \\
\hline \multirow{2}{*}{$500 \mathrm{~Hz}$} & Canal wall up tympanoplasty & $32.50 \pm 12.38$ & $27.19 \pm 11.07$ & 0.039 \\
& Canal wall down tympanoplasty & $39.06 \pm 14.67$ & $36.09 \pm 14.01$ & 0.142 \\
\multirow{2}{*}{$1000 \mathrm{~Hz}$} & Canal wall up tympanoplasty & $34.69 \pm 13.67$ & $29.53 \pm 10.73$ & 0.039 \\
& Canal wall down tympanoplasty & $39.22 \pm 14.87$ & $37.81 \pm 14.86$ & 0.397 \\
$2000 \mathrm{~Hz}$ & Canal wall up tympanoplasty & $28.43 \pm 10.88$ & $21.72 \pm 9.97$ & 0.004 \\
& Canal wall down tympanoplasty & $36.41 \pm 10.94$ & $33.75 \pm 11.43$ & 0.074 \\
$4000 \mathrm{~Hz}$ & Canal wall up tympanoplasty & $27.34 \pm 12.51$ & $23.59 \pm 10.49$ & 0.021 \\
& Canal wall down tympanoplasty & $32.81 \pm 11.21$ & $30.31 \pm 12.70$ & 0.065 \\
\hline
\end{tabular}

Note : ABG: air bone gaap

\section{DISCUSSION}

No significantly different was observed in the mean of patients age and sex distribution of the both groups. The results of this mean age and sex distribution were consistent with the results reported by Shyfakumar et al. ${ }^{10}$ which showed the pateints mean was $30.14 \pm$ 0.98 years consisting $24(48 \%)$ male and 26 (52\%) among 50 CSOM patients involved in their study. It was indicated that the CSOM 
became a major problem in the productive age in the male and femal patients.

The AC and BC hearing thresholds of CSOM patients undergoing canal wall up tympanoplasty at each audiometric frequency (TABLE 2 and 4) were significantly different compared to those who undergoing canal wall down tympanoplasty $(\mathrm{p}=0.001)$. These suggest a more severe in hearing loss in patients underwent canal wall up tympanoplasty than in canal wall down tympanoplasty group. The CSOM patients have pathological abnormalities with the extension of pathological tissue and cholesteatoma reaching to mesotympany and hypotympanic areas so that there is damage to the circuit of hearing bone and also happened fixation of stapes foot which impact on decreasing threshold reach $60 \mathrm{~dB}$ or more. ${ }^{2,11}$ Albera et al. ${ }^{12}$ reported that $82 \%$ of patients with malignant/ cholesteatoma CSOM had impaired or impaired hearing bone chain. More than $78 \%$ of damage occurred in incus auditory bone and more than $45 \%$ of damage occurred in more than one hearing bone. This results in heavier conductive deafness when compared with CSOM patients in the absence of cholesteatoma in addition to the presence of cholesteatoma tissue in a nice round window region will result in impedance and phase disturbance in the oval and transparent lobes resulting in noise conduction disturbance in the cochlea. ${ }^{11,13}$

Other factors that may result in decreased bone conduction in patients with CSOM are influenced by: 1) sealed or obliterated round window by middle ear granulation tissue that affects the loss of phase difference between round window and oval window, 2) stiffness of hearing bone as a result of granulation tissue and cholesteatomas that envelop the hearing bones, 3) perforation and discontinuities of the hearing bone. ${ }^{4}$
The difference between the air-bone conductivity range in each groups of both canal wall up and canal wall down tympanoplasty is statistically significant, especially at 2000 $\mathrm{Hz}(\mathrm{p}=0.005)$. The diagnosis and management of each group sample has been adjusted for clinical indications and considerations for the selection of surgical procedures. Patients with a diagnosis of chronic active suppurative otitis media of unsigned benign/ unsafe type performed canal wall up tympanoplasty procedures, while patients with chronic malignant suppurative otitis media were performed by canal wall down tympanoplasty surgery. The selection of these two surgical techniques is based on the extension of the pathologic/ cholesteatoma tissue, access to reach the tympanic cavity area, the threshold value and the presence or absence of both intratemporal and intracranial complications. ${ }^{11}$

The significantly differences between AC hearing thresholds on canal wall up tympanoplasty and canal wall down at frequencie 500 and 1000 and $2000 \mathrm{~Hz}$ was oserved $(p<0.05)$. However, there is significantly differences at frequencies 4000 $\mathrm{Hz}(\mathrm{p}=0.515)$. This suggests that the surgery performed on the CSOM patients accompanied by a good middle ear reconstruction with canal wall up tympanoplasty techniques and canal wall down tonnage can improve the conduction system in the auditory process. This result does not differ greatly from the previous study research in which the preoperation airspeed threshold at frequencies $500,1000,2000$ and $3000 \mathrm{~Hz}$ at $51 \pm 13 \mathrm{~dB}$ and after surgery to $40 \pm 11 \mathrm{~dB} .{ }^{14}$

Significantly differences in outcome of the air-bone conduction range, especially in the canal wall up tympanoplasty group before and after surgery at all frequencies (TABLE 4) were observed $(p<0.05)$. However, no significantly differences of the air-bone conduction range 
in canal wall down tympanoplasty group were observed as shown in TABLE 4 ( $p>0.05)$. This result are similar to the previous study which reported that no significantly differences in air-bone conduction in ABG between canal wall up tympanoplasty and canal wall down tympanoplasty after surgery with a value of $10.9 \mathrm{~dB}$ in canal wall uptank and $13.5 \mathrm{~dB}$ on the wall tympanoplasty collapsed. ${ }^{15}$

\section{CONCLUSION}

In conclusion, canal wall up tympanoplasty in CSOM patients is better to improve hearing threshold compared to canal wall down tympanoplasty.

\section{ACKNOWLEDGEMENTS}

We would like to thank our collagues from Department of OtorhinolaryngologyHead and Neck Surgery, Faculty of Medicine, Publich Health, and Nursing, Universitas Gadjah Mada/Dr. Sardjito General Hospital, Yogyakarta who have supported this study

\section{REFERENCES}

1. Shetty S. Pre-operative and postoperative assessment of hearing following tympanoplasty. Indian J Otolaryngol Head Neck Surg 2012; 64:377-81.

2. Helmi. Otitis media supuratif kronik. In: Otitis media supuratif kronik: pengetahuan dasar, terapi medik, mastoidektomi, timpanoplasti. Jakarta: Balai Penerbit FKUI 2005.

3. Weber PC. Chronic otitis media. In: Hughes GB, Pensak ML, editors. Clinical otology $3^{\text {rd }}$ ed. New York: Thieme. 2007: 236-49.

4. Vijayendra H, Parikh B. Bone conduction improvement after surgery for conductive hearing loss. Indian J Otolaryngol Head Neck Surg 2011; 63(3):201-4
5. Shrestha BL, Bhusal CL, Bhattarai H. Comparison of pre and post-operative hearing results in canal wall down mastoidectomy with type III tympanoplasty. J Nepal Med Assoc 2008; 47(172):224-7.

6. Keputusan Menteri Kesehatan Republik Indonesia No. 879/Menkes/SK/XI/2006. Rencana Strategi Nasional Penanggulangan Gangguan Pendengaran dan Ketulian untuk Mencapai Sound Hearing 2030. Jakarta: Kementerian Kesehatan Republik Indonesia, 2006.

7. Rianto BUD. Kholesteatom timpani. Yogyakarta: Badan Penerbit Universitas Gadjah Mada, 2013.

8. Ocalan R, Ocalan FCA, Genc S, Titiz A, Unal A. Hearing results in patients undergoing canal wall down mastoidectomy with type III tympanoplasty. J Med Updates 2013; 3(2):77-81.

9. Slattery III WH. Pathology and clinical course of inflammatory diseases of the middle ear. In: Glasscock II ME, Gulya AJ, editors. Glasscock-Shambaugh surgery of the ear. $5^{\text {th }}$ ed. Ontario: BC Decker Inc. 2003: 422-35.

10. Shivakumar KL, Joshym S, Mary. Role of cortical mastoidectomy in inactive mucosal type of chronic otitis media. J Evid Based Med Health Care 2014; 1(7):509-17.

11. Offeciers E, Vercruyss JP, Foer BD, Casselman J, Somers T. Mastoid and epitympanic obliteration the bony obliteration technique. In: Bernar Ars editor. Chronic otitis media pathogenesis oriented therapeutic management. Amsterdam: Kugler Publication 2009: 299-323

12. Albera R, Dagna F, Filippini C, Albera A, Canale A. Ossicular chain lesions in tympanic perforations and chronic otitis media without cholesteatoma. J Int Adv Otol. 2015; 11(2):143-6.

13. Viswanatha B, Naseeruddin K, Ravikumar R, Vijayashree MS, Krishna N. Sensorineural 
hearing loss in complicated cholesteatomatous ear disease. Res Otolaryngol 2014; 3(2):2935 .

14. Mahadevaiah A, Parikh B. Modified intact canal wall mastoidectomy long term result in hearing and healing. Indian J Otolaryngol Head Neck Surg 2008; 60: 317-23.

15. Heywood RL, Narula AA. The pros and cons of canal wall up versus canal wall down mastoidectomy for cholesteatoma. Otorhinology 2013;6(3):140-3. 